\title{
THE REAL-TIME PCR FOR DETECTION OF EQUINE ARTERITIS VIRUS
}

\author{
I. Chenchev, L. Polychronova, S. Chakarova, I. Genova \\ Laboratory of AHS, National Diagnostic Research \\ Veterinary Medical Institute, Sofia, Bulgaria
}

\section{Abstract}

The aim of this study was to develop and validate the real-time RT-PCR method in detection of the equine arteritis virus in the nasal swabs, semen plasma and whole blood samples from horses with clinical signs of the disease. The 66 samples - 28 nasal swab samples from mares, 23 semen plasma samples from stallions, 6 whole blood samples from stallions and mares, 7 samples - 10\% internal organ tissues suspensions from aborted foetus were used in investigation. Two reference strains „ARVAC” and "Bucyrus" were used as the positive controls. RNA was isolated from cell culture supernatant fluid which was infected with reference viruses and whole blood from infected animals by commercial kit Viral RNA Mini Kit (Qiagen, Germany). The real-time RT-PCR - one step protocol, developed by Balasuriya et al. (2002) was used for the amplification of the 204 bp ORF7 segment of the EAV genome. The $96 \%$ of samples showed the positive results by real time RT-PCR. The $3.5 \%$ we investigated again and only $0.5 \%$ of the samples were negative. The controls tested positive and this contributed for precise interpretation of the obtained results. The samples which show high CT values were amplified again only with primers and the products were visualized in $2 \%$ agarose gel. The positive reaction products show the DNA fragments of about $200 \mathrm{bp}$.

Key words: equine viral arteritis, clinical signs, diagnosis, laboratory methods 


\title{
UPOTREBA METODE LANČANE REAKCIJE POLIMERAZE U STVARNOM VREMENU ZA DETEKCIJU KONJSKOG ARTERITIS VIRUSA
}

\author{
I. Chenchev, L. Polychronova, S. Chakarova, I. Genova \\ Laboratory of AHS, National Diagnostic Research \\ Veterinary Medical Institute, Sofia, Bulgaria
}

\section{Kratak sadržaj}

Cilj ovog ispitivanja je bio da se razvije i validira metoda reverzne transkripcije- lančane reakcije polimeraze u stvarnom vremenu („real-time RT-PCR“) za detekciju virusa virusnog arteritisa konja u uzorcima nosnih briseva, seminalnoj plazmi i heparinisanoj krvi konja sa kliničkim znacima bolesti. U tu svrhu je ispitano 66 uzoraka - 28 nosnih briseva kobila, 23 seminalne plazme pastuva, 6 uzoraka heparinisane krvi kobila i pastuva, 7 uzoraka 10\% suspenzije unutrašnjih organa pobačenih fetusa. Pozitivne kontrole su bile dva referentna virusna soja $z \mathrm{i}$ „Bucyrus”. RNK je estrahovana iz supernatanta ćelijskih kultura, koje su bile inficirane ili virusnim kontrolama ili heparinisanom krvi inficiranih životinja, sa komercijalnim kitom „Viral RNA Mini Kit“ („Qiagen“, Nemačka). Za umnožavanje segmenta $O R F 7$ dela genoma konjskog arteritis virusa $(E A V)$ u dužini od 204 bazna para upotrebljen je real-time RT-PCR - jednostepeni protokol razvijen od strane Balasuriya i sar. (2002). Pozitivnu real-time RT-PCR reakciju je dalo $96 \%$ ispitanih uzoraka. Ponovo je ispitano $3,5 \%$ uzoraka i samo $0,5 \%$ je dalo negativan nalaz. Sve kontrole u reakcijama su dale očekivane nalaze, što je doprinelo tačnosti interpretacije utvrđenih rezultata. Uzorci koji su imali visoke $C T$ vrednosti su umnožavani u ponovljenim reakcijama ali samo sa prajmerima, bez korišćenja probe, a produkti su posmatrani nakon elektroforeze na $2 \%$ agaroznom gelu. $\mathrm{U}$ slučajevima pozitivnih nalaza utvrđivani fragmenti na gelu su bili veličine oko 200 baznih parova.

Ključne reči: virusni arteritis konja, klinički znaci, dijagnostika, laboratorijske metode

\section{INTRODUCTION}

Equine viral arteritis (EVA) is a highly contagious equine disease with a wide distribution throughout the world. It is caused by a specific viral infection, which can cause fever, depression and oedema (swelling) especially of the limbs and inflammation around the eyes. The virus may cause abortion in pregnant mares and severe respiratory disease in young foals. The disease has around 30\% mortality in its start and later is increased and reaches up 
to 80\% (Chirnside, 1992; Fukunga, 1994; Glaser et al., 1996; Timoney and McCollun, 1993).

Stallion is a very important source of the virus. On infection, the virus is present in his accessory sex glands and the stallions can shed the virus in semen for several weeks afterwards, or for many months or years and possibly for life. After recovery from acute illness, stallion's fertility is not affected and will show no further clinical signs of infection even though it may still be infectious. Shedder stallions will infect susceptible mares during mating, or after insemination with the stallion's semen, and these mares may, in turn, infect in-contact animals via the respiratory route. Presence of equine arteritis virus (EAV) in the semen fluid of the stallions, some difficulties in time to take the sample from stallions and difficult isolation of the virus on cell cultures are the most important reasons for the application of different PCR methods (Timoney and McCollum, 1993; Mann, 1998).

In Bulgaria the disease was detected 7 years ago. As laboratory test in confirmation of the infection the recommend method will be direct isolation of the virus from semen fluid (Klug and Sieme, 1999). The virus neutralization method and ELISA are the other most useable and applicable methods in sero-surveillance monitoring among the solipades population (Hyllseth and Pettersson, 1970; Maess, 1971; Radwan and Crawford, 1974). Also, in virus detection, sensitive RT-PCR for virus detection in infected cell culture and semen fluid were carried out by many authors (St-Laurent et al. 1994; Sekiguchi et al. 1995; Gilbert et al. 1997; Starick, 1998 and Ramina et al. 1999). Using of the real-time PCR in diagnostic system is facilitated from adequate quantity of the target DNA and RNA (Holland et all, 1991; Higuchi et all, 1993; St-Laurent et all, 1994; Livak et all, 1995; Sekiguchi et all, 1995; Gilbert et all, 1997; Ramina et all, 1999; Leutenegger, 2001; Leutenegger et al., 2001; Udeni et all, 2002). Difficulties in EAV detection in semen fluid of stallions and difficulties in collection of the semen samples facilitating the development of different RT-PCR reactions in the diagnostic system of this disease (Timoney and McCollun, 1993; Mann, 1998). Balasuriya et al. (1998) and Edwards et al. (1999) developed the realtime RT-PCR protocols by using the specific primers for ORF7 genome segment that amplify fragment of about 200 base pair.

The aim of this study was to develop and validate the real-time RT-PCR method in detection of the equine arteritis virus in the nasal swabs, semen plasma and whole blood samples from horses with clinical signs of the disease.

\section{MATERIAL AND METHODS}

The 66 samples - 28 nasal swab samples from mares, 23 semen plasma samples from stallions, 6 whole blood samples from stallions and mares, 7 samples - 10\% internal organ tissues suspensions from aborted foetus and, for the control of the reaction, two reference strain - „ARVAC” and "Bucyrus” were used in investigation. 
Virus isolation - Nasal swabs of stallions and mares for virus isolation were collected into clean centrifuge tubes with cell culture medium 199, containing antibiotics. The content of tubes were mixed briefly by vortex. Then, the suspensions were centrifuged at $1000 \mathrm{~g}$ for $10 \mathrm{~min}$ and the clear supernatant fluids were collected for virus isolation.

RNA was isolated from cell culture supernatant fluid which is infected with viral strains or whole blood from infected animals by commercial kit Viral RNA Mini Kit (Qiagen, Germany) according to the manufacturer instruction. For RNA extraction $140 \mu \mathrm{l}$ from cell culture samples and $280 \mu \mathrm{l}$ from the other clinical samples were used. The extracted RNA was diluted in $50 \mu \mathrm{l}$,nuclease-free" water and kept before examination in freezer $-80^{\circ} \mathrm{C}$.

Real-time RT-PCR - one step protocol which is developed by Balasuriya et al. (2002) was used with Applied Biosystems 7300 machine (Applied Biosystems, Foster City, CA). According the one step protocol, the reverse transcription of the viral RNA is followed with amplification of the $204 \mathrm{bp}$ segment from the open reading frame 7 (ORF7) of the EAV genome. The Forward Primer - EAV7.53F -GGCGACAGCCTACAAGCTACA in working dilution $20 \mathrm{pmol} / \mathrm{ul}$; Reverse Primer EAV7.256R -CGGCATCTGCAGTGAGTGA in working dilution 20 pmols/ul and probe EAV7.92P- 6FAM-TTGCGGACCCGCATCTGACCAA-TAMRA in working dilution $5 \mathrm{pmols} / \mathrm{ul}$ were used in the reaction. Also we used different volumes of primers and probe to validate the results of the reaction.

The volumes of reagents per $25 \mu \mathrm{l}$ reaction mix was: $12.5 \mu \mathrm{l}$ TaqMan Universal PCR master mix (2X) (Applied Biosystems, Foster City, CA) with the passive reference color - ROX, $0.6 \mu \mathrm{l}$-Moloney Murine Leukemia Virus (MuLV) and RNase inhibitor mix (40X; Applied Biosystems, Foster City, CA), $80 \mathrm{nM}$ of fluorogenic probe $(0.2 \mu \mathrm{l}), 800 \mathrm{nM}$ of each primer $(0.5 \mu \mathrm{l})$ free nuclease water $\mathrm{ddH} 2 \mathrm{O}(0.7 \mu \mathrm{l})$ and $10 \mu \mathrm{l}$ RNA extract from the investigated samples or from positive control standard.

The thermal cycling was $48^{\circ} \mathrm{C}$ for $35 \mathrm{~min}, 90^{\circ} \mathrm{C}$ for $10 \mathrm{~min}-50$ cycles of $95^{\circ} \mathrm{C}$ for $15 \mathrm{sec}$ and $60^{\circ} \mathrm{C}$ for $1 \mathrm{~min}$. The amplifications are made in ABI PRISM 7300 (Applied Biosystems, Foster City, CA). The positive results are detected in real time by the transmission of the report fluorescence rates. The information of the obtained products is automatically estimated in the end of the third cycle step of amplification and extension.

Sometimes we are visualized the obtained amplicons by electrophoresis in $2 \%$ agarose gel with $100 \mathrm{~V}$ for $3 a 90 \mathrm{~min}$. After electrophoresis we stained the gel by the etidium bromide solution (in final concentration $0.5 \mu \mathrm{g} / \mathrm{ml}$ ) for $10 \mathrm{~min}$ and we visualised the results by UV transiluminator photo picture systems. The size of PCR products are estimated by using DNA marker of $100 \mathrm{bp}$ (Gibco BRL, USA). 


\section{RESULTS}

The protocol for the real-time RT-PCR reaction is optimized in the part of quantity of the used reagents and RNA extract. We accepted for the positive reaction the results which showed the positive signal between 31 and 45 working cycle. The results of the reaction are presented in the Table 1.

Table 1: Results of the real-time RT-PCR in detection of EAV in the clinical samples

\begin{tabular}{|c|c|c|c|}
\hline Kind of sample & Position & Ct & Results \\
\hline Nasal swab & A1 & 32.62 & + \\
\hline Semen fluid & B1 & 32.59 & + \\
\hline Semen fluid suspention & C1 & 36.01 & + \\
\hline Whole blood & D1 & 37.13 & + \\
\hline Positive control Arvac & E1 & 33.82 & + \\
\hline Positive control Bucyrus & F1 & 33.89 & + \\
\hline Negative control & G1 & - & - \\
\hline
\end{tabular}

We observed the positive results in nasal swab and semen fluid between 31 and 43 amplification cycles. The obtained result from reaction is presented in Figure 1.

Figure 1: Amplification plot of obtained real-time RT-PCR reaction

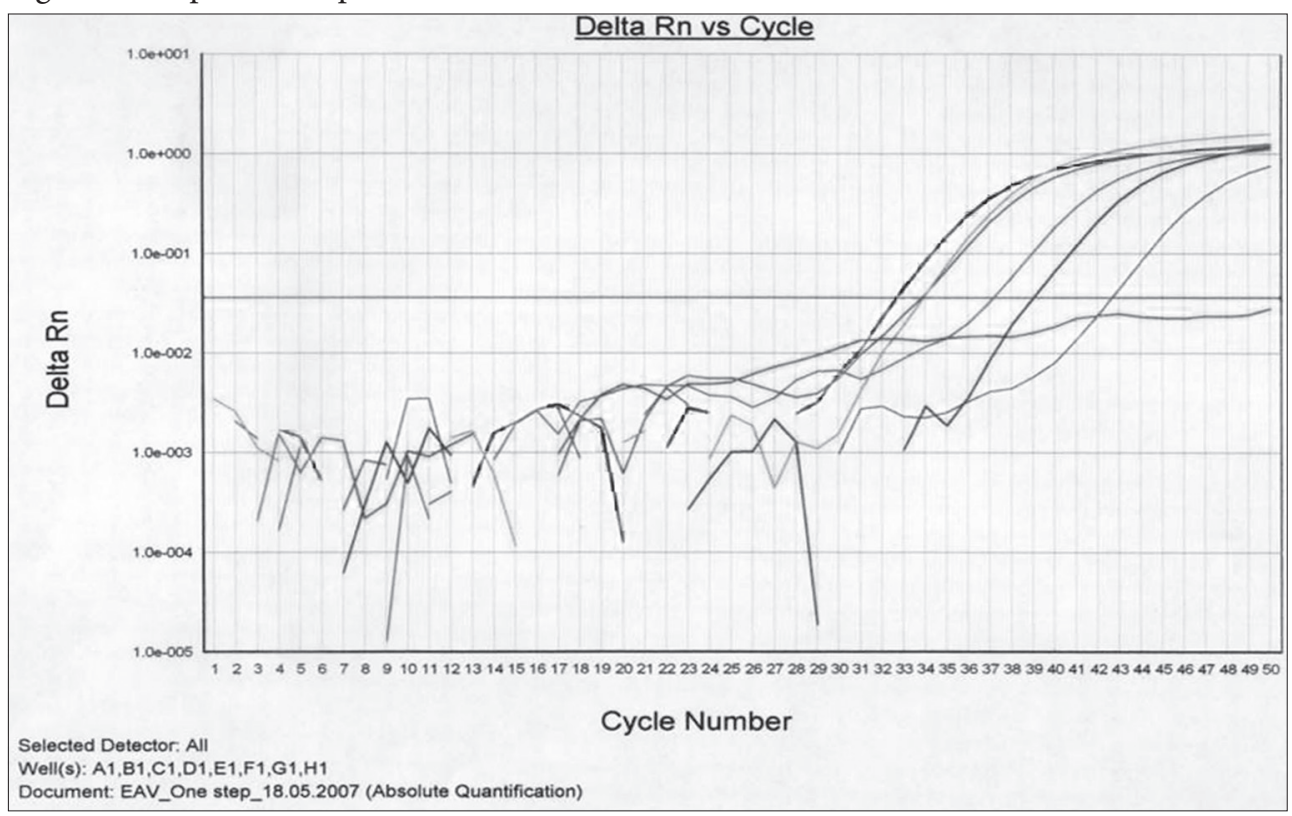


The samples which show high CT values were amplified again only with primers and the products were visualized in $2 \%$ agarose gel. The positive reaction products show the DNA fragments of about $200 \mathrm{bp}$ (Figure 2).

Figure 2: Results of the amplification on $2 \%$ agarose gel. Positive reaction products show the DNA fragments of about $200 \mathrm{bp}$

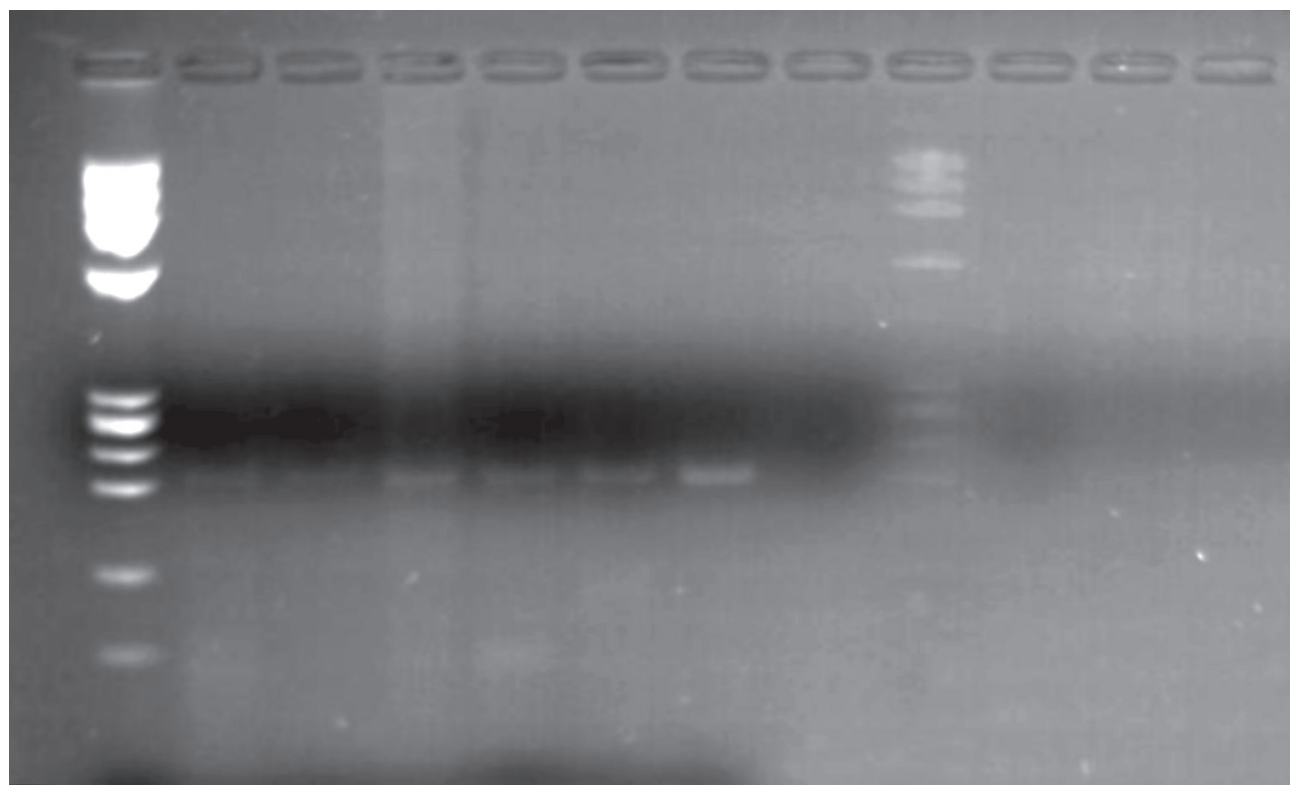

As the part of presented work the working laboratory real-time RT-PCR protocol for the detection of equine arteritis virus genome in semen fluid and whole blood was developed and standardized.

\section{DISSCUSION}

We estimated the critical fluorescence level (Ct) of each sample from short cut point of the sample and exponential curve of base line. The fluorescence level of each sample is counted after third step of amplification. The positive reaction is visualized from exponential curve which has done from the fluorescence points of the samples by the software program.

The negative results are visualized as absence of exponential curve. We counted the samples like a negative with very high Ct level and if it didn't cross the base line (treashold). The last we named like "No Ct". The total number of amplification cycles 
in reaction was 50 and the optimal value of $\mathrm{Ct}$ for positive samples were from 18 to 38 cycles. All samples which have showed the high value in lower limits level we investigated again. In time of reaction we made some corrections in respect of concentration and dilution on RNA.

The $96 \%$ of samples showed the positive results by real time RT-PCR. The $3.5 \%$ we investigated again and only $0.5 \%$ of the samples were negative. All controls of the reaction were worked and this contributed for precise interpretation of the obtained results.

\section{CONCLUSIONS}

1. As the results of our investigations we developed, optimized and applied the one step real-time RT- PCR for detection of equine arteritis virus in semen fluid, whole blood and other biological material.

2. The better results are observed when duble amount of the primers and probe were used.

3. The methods we used needs additional optimizing regarding its working condition and the good results were observed by using of one step Real Time RT-PCR method.

\section{LITERATURE}

1. Balasuriya, U.B.R., Evermann, J.F., Hedges, J.F., McKeirnan, A.J., Mitten, J.Q., Beyer, J.C., McCollum, W.H., Timoney, P.J., MacLachlan, N.J.: Serologic and molecular characterization of an abortigenic strain of equine arteritis virus derived from infective frozen semen and an aborted equine fetus. J Am Vet Med Assoc, 213, 1586-1589, 1998.

2. Balasuriya U.B.R., Leutenegger C.M., Topol J.B., McCollum W.H., Timoney P.J., MacLachlan N.J.: Detection of equine arteritis virus by real-time TaqMan ${ }^{\oplus}$ reverse transcription-PCR assay. Journal of Virological Methods, 101, 21-28, 2002.

3. Belak, S., A. Ballagi-Pordany, P.J. Timoney, W.H. McCollum, T.V. Little, B. Hyllseth, B. and B. Klingeborn: Evaluation of a nested PCR assay for the detection of equine arteritis virus, p. 33-38. In: H. Nakajima and W. Plowright (eds.), Proceedings of the 7th International Conference on Equine Infectious Diseases, Tokyo, Newmarket, England: R \& W pubblications, 1994.

4. Chirnside, E.D.: Equine Arteritis Virus: an Overview. British Veterinary Journal 148, 181-197, 1992.

5. Chirnside E.D., de Vries A.A.F., Mumford J.A., Rottier P.J.M.: Equine arteritis virus-neutralizing antibody in the horse is induced by a determinant on the large envelope glycoprotein GL. J Gen Viro,1 76, 1989-1998, 1995. 
6. Edwards, S., Castillo-Olivares, J., Cullinane, A., Lable, J., Lenihan, P., Mumford, J.A., Paton, D.J., Pearson, J.E., Sinclair, R., Westcott, D.G.F., Wood, J.L.N., Zientara, S., Nelly, M.: International harmonisation of laboratory diagnostic tests for equine viral arteritis. In: U. Wernery, J.F.Wade, J.A.Mumford \& O. Kaaden Eds., Proceedings of the Eighth International Conference on Equine Infectious Diseases, R\&W Publications, pp 359-362, 1999.

7. Fukunaga, Y.: Equine viral arteritis: Diagnostic and control measures. J Equine Sci, 5, 101-114, 1994.

8. Gilbert, S.A., Timoney, P.J., Deregt, D.: Detection of equine arteritis virus in the semen of carrier stallions by using a sensitive nested PCR assay. J Clin Microbiol, 35, 2181-2183, 1997.

9. Glaser, A.L., Rottier, P.J.M., Horzinek, M.C., Colenbrander, B.: Equine arteritis virus: a review of clinical features and management aspects. Vet Quart, 18, 95-99, 1996.

10. Higuchi, R., Fockler, C., Dollinger, G., Watson, R.: Kinetic PCR: real time monitoring of DNA amplification reactions. Biotechnology 11, 1026-1030, 1993.

11. Holland, P.M., Abramson, R.D., Watson, R., Gelfand, D.: Detection of specific polymerase chain reaction products by utilizing the $5^{\prime}$ to $3^{\prime}$ exonuclease activity of Thermus aquaticus DNA polymerase. Proc Natl Acad Sc USA, 88, 7276-7280, 1991.

12. Hyllseth, B. and Pettersson, U.: Neutralization of equine arteritis virus: enhancing effect of guinea pig serum. Arch Gesamte Virusforsc,h 32, 337-347, 1970.

13. Klug, E. and Sieme, H.: Tierärztliche Empfehlungen zum Umgang mit der Equinen Virusarteritis. Tierärztl Pra,x 27, 61-66, 1999.

14. Leutenegger, C.M.: The real-time TaqMan PCR and applications in veterinary medicine. Vet. Sci. Tomorrow, 1-15, 2001.

15. Leutenegger, C.M, Alluwaimi, A.M., Smith, W., Perani, L., Cullor, J.M.: Quantitation of bovine cytokine mRNA in milk cells of healthy cattle by real-time TaqManR polymerase chain reaction. Ve. Immunol Immunopathol, 77, 275-287, 2001.

16. Livak, K.J., Flood, S.J.A., Marmaro, J., Giusti, W., Deetz, K.: Oligonucleotide with fluorescent dyes at opposite ends provide a quenched probe system useful for detecting PCR product and nucleic acid hybridization. PCR Methods App. 4, 357362, 1995.

17. Mann, A.W.: Addressing equine viral arteritis in the United States. Proc Annu Meet US Anim Health Assoc, pp. 259-264, 1997.

18. Mann, A.W.: Equine viral arteritis. Proc Annu Meet US Anim Health Assoc, pp. 314-316, 1998.

19. Maess, J.: Complement dependent neutralization of equine arteritis virus. Arch Gesamte Virusforsc,h 33, 194, 1971. 
20. Radwan, A.I., Crawford, T.B.: The mechanisms of neutralization of sensitized equine arteritis virus by complement components. Am J Vet Res 35, 181-185, 1974.

21. Ramina, A., Valle, L.D., De Mass, S., Tisato, E., Zuin, A., Renier, M., Cuteri, V., Valente, C, Cancellotti, F.M.: Detection of equine arteritis virus in semen by reverse transcriptase polymerase chain reaction-ELISA. Comp Immunol Microbiol Infect Dis, 22, 187-197, 1999.

22. Starick, E., Ginter, A. Coppe, P.: ELISA and Direct Imunofluorescence test to detect equine arteritis virus (EAV) using a monoclonal antibody directed to the EAV-N protein. J Vet Med 48, 1-9, 2001.

23. St-Laurent, G., Morin, G., Archambault, D.: Detection of equine arteritis virus following amplification of structural and nonstructural viral genes by reverse transcription-PCR. J Clin Microbiol, 32, 658-665, 1994.

24. Sekiguchi, K., Sugita, S., Fukunaga, Y., Kondo, T., Wada, R., Kamada, M., Yamaguchi, S.: Detection of equine arteritis virus (EAV) by polymerase chain reaction (PCR) and differentiation of EAV strains by restriction enzyme analysis of PCR products. Arch Virol, 140, 1483-1491, 1995.

25. Timoney, P.J. McCollum, W.H.: Equine viral arteritis in perspective in relation to International trade. J Equine Vet Sc, 13, 50-52, 1993.

Primljeno: 15.05.2010.

Odobreno: 17.06.2010. 